\title{
Reproductive biology of the squid Loligo forbesi (Cephalopoda: Loliginidae) in the Egyptian Mediterranean waters
}

\author{
Rafik Riad $^{1}$ and Hamida A. AL Werfaly ${ }^{2}$ \\ 1- National Institute of Oceanography and Fisheries, Alexandria, Egypt \\ 2- Zoology Department, Faculty of Science, Ain Shams University, Cairo, Egypt \\ rafik_riad67@yahoo.com
}

\begin{abstract}
Reproductive biology of males and females Loligo forbesi were investigated from samples obtained from commercial catch caught by local fishermen using trawling nets. The samples were seasonally collected (548 individuals) between spring 2010 and winter 2011. The results of sex ratio indicated that females outnumbered males during peak periods of reproduction. Based upon morphological features of the gonads, two and five maturity stages for males and females were described, respectively. Depending on the proportion of each maturity stage, as well as various maturity indices (gonado-somatic index, G.S.I and nidamental- somatic index, N.S.I) the spawning season was found to take place during spring and early summer. The mean size at first maturity was 13 and $11.8 \mathrm{~cm}$. dorsal mantle length (ML) for males and females respectively.
\end{abstract}

Keywords: Squid, Loligo forbesi, reproductive biology, Mediterranean, Egypt.

\section{INTRODUCTION}

Loliginids play an important role in the marine food chain. They belong to the third trophic level in the food chain. They contain about 500 species of squids in different seas and oceans (Sweeney and Vecchione, 1998). Their sizes range from 1-2 inches in the tiny squids, Idiosepius pygmaeus, to 60 feet of the giant squid, Architeuthis sp. Squids are divided into two groups; the myopsid and the oegopsid (Sweeney and Vecchione, 1998). The myopsid group inhabits the continental shelf regions and has covered eyes; however the oegopsids live in the open ocean. The major exploited family of myopsid squids is Loliginidae, with major genera, Loligo, Photololigo and Sepioteuthis. Despite the abundance of loliginids in the continental shelf habitats and their commercial and scientific importance, loliginidae classification and phylogeny remain confused (Vecchione et al., 1998).

Regarding the distribution of Loligo forbesi, it extends throughout the Mediterranean and Red Sea, Eastern Atlantic (excluding the Baltic Sea), on the Azores Islands and along West African coast south to the Canary Islands (Roper et al., 1984). It is commonly found in the following areas of the United Kingdom: the English Channel (Holme, 1974), the Irish Sea (Collins et al., 1995), Rockall Bank and the Scottish west coast (Pierce et al., 1994a) and in the Moray Firth (Young et al., 2006). In Egypt, Loligo forbesi range extends from south to the Mediterranean to the Gulf of Suez in the Red Sea (Pierce et al., 1998).

Gabr and Riad (2008) stated that Loligo forbesi is one of the important fishery resources in the Suez bay; it is captured mainly as a bycatch of artisanal trawling techniques and is caught directly by a manual jigging technique. Out of 299 trawling operations in Alexandria Mediterranean waters, the cephalopods are represented about $9.8 \%$ of the total fish catch landing, of which $6.1 \%$ cuttlefishes, $3.5 \%$ octopuses and $0.21 \%$ squids (Riad, 1993). Investigation of 149 trawling operations in Alexandria Mediterranean waters in the period from 1986-1988, cuttlefishes, octopuses and squids were found to represent 6.13, 1.47 and $0.09 \%$, respectively of the total catch (Rizkalla, 1992). Worth mentioning is that the squid 
catch represents less than $10 \%$ of the total annual landing from the Egyptian Fishers (Riad and AbdEl-Hafez, 2008).

Life history and biology of Loligo forbesi have been thoroughly investigated in various locations. Holme (1974) reported on its life history in the English Channel. Howard (1979), Gaard (1987), Lum-Kong et al. (1992), and Pierce et al. (1994a) described some biological aspects of the species off Scotland and the Faroe Islands. Moreover, Collins et al. (1993) recorded some biological data from the Irish and Celtic seas, whereas Guerra and Rocha (1994) described the life history of Loligo forbesi and its populations along the Adriatic coast of northwest Spain. Meanwhile, Cunha and Moreno (1994) studied Loligo forbesi stocks from continental Portugal waters. In the UK, Pierce et al. (2005) studied the interannual variation in life-cycle characteristics of the same species in the Scottish waters. Seasonality of maturation, with a single breeding episode during winter months is the pattern for Loligo forbesi (Holme, 1974; Martins, 1982; Boyle and Ngoile, 1993; Pierce et al., 1994a) on both west and east coasts of the North Atlantic. Loligo forbesi have an approximate year life span (Collins et al., 1997, 1999), although some may continue to live as long as 18 months (Rocha and Guerra, 1999). Maturity of the Veined Squid occurs at a range of sizes, with males typically growing to a larger size than females (Hastie et al., 2009) but maturity is typically reached by $200 \mathrm{~mm}$ mantle length individuals (Challier et al., 2005).

Most of previous carried out investigations have focused on growth of Loligo forbesi using the gonado-somatic index (GSI) (Portiero and Martins, 1994; Boyle et al., 1995, Collins et al., 1995). Information on maturation and spawning of Loligo forbesi will contribute to our knowledge of its general biology, population dynamics, and management of their stocks.

The current study was designed to address the lack of information regarding the reproduction biology of Loligo forbesi in the Mediterranean Sea. The work presents the first detailed study of seasonal variation in sexual maturity, length-frequency distribution and age. The study also documents the spawning season and length at first maturity of the species in the area.

\section{MATERIALS AND METHODS}

Seasonal specimens of the squid Loligo forbesi were collected (548 individuals) between spring 2010 and winter 2011 off the coasts of Alexandria, Egypt. The samples were caught by local fishermen using trawling nets. All specimens were frozen and stored till examined. After thawing at room temperature, the total body wet weight (To.Wt), gonad weight (G.Wt) and Nidamental weight (N.Wt) to the nearest $0.1 \mathrm{gm}$ and dorsal mantle length (ML) to the nearest $1 \mathrm{~mm}$. were measured and recorded. The sex was determined by checking the left arm IV hectocotylized (modified arm) typical of males (Richard 1967). Length at first maturity is determined according to Snedecor (1956), which is the mantle length at which $50 \%$ of the Loligo forbesi are mature. Reproductive status indices (Joy 1989; Pierce et al. 1994a) were calculated for males and females in each season. The indices are Gonadosomatic Index (GSI) for both sexes and the Nidamental-Somatic Index (NSI) for the females, were calculated as follows:

$\mathrm{GSI}=\mathrm{G} . \mathrm{Wt} * 100 /$ Total.Wt

$\mathrm{NSI}=\mathrm{NG} . \mathrm{Wt} * 100 /$ Total.Wt

Where G.Wt is the gonad weight; To.Wt is total body weight and N.Wt is the nidamental gland weight. Maturity stages of the specimens were determined. The presence of spermatophoric sacs was detected in males, a simplified system of maturity stages was adopted based on a modified Lipinski (1979) scale which is as follows: I- immature, and IImature, On the other hand, the white, orange, red, coral and rose color of the accessory 
nidamental gland in females indicated the different maturity stages (Richard 1967; Riad 1993). Sex ratio, tabulation of the number of males and females, mature and immature individuals of each sex, was determined.

\section{RESULTS}

\section{1- Gonado and nidamental gland-somatic index.}

a) Gonado-somatic index (G.S.I).

It is worth to note that the spawning season can be predicted from seasonal variations in gonadal size. The start of a gonadal increase in gonado-somatic index (G.S.I) is an indication of breeding season onset. The G.S.I attains its maxima during breeding time. The G.S.I of 310 males and 238 females Loligo forbesi were calculated. Obviously, the seasonal variation trend in G.S.I was found to be more or less like the same for males and females belonging to this species (Fig. 1).
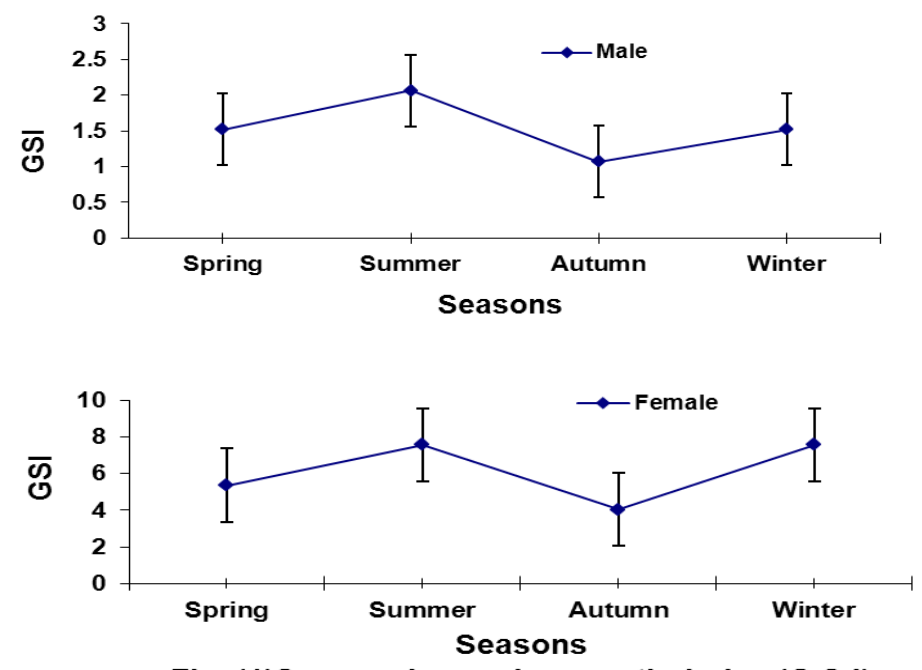

Fig. (1)Seasonal gonado-somatic index (G.S.I) for Loligo forbesi

G.S.I minimal values were attained during autumn. The G.S.I for males and females clarified a gradual increase starting in winter, attaining its highest values with a peak during summer (Fig. 1). Thus, we can deduct that spawning peak of both sexes occurs during spring and early summer.

\section{b) Nidamental gland- somatic index (N.S.I).}

Female cephalopods have nidamental glands whose function is to secrete a substance for egg protection. Spawning is accompanied by emission of this substance, which envelops the egg, which is then being attached to a substrate (Bakhayokho, 1983). At the time of spawning females have enlarged nidamental glands. The variations in the N.S.I could therefore, like those of the G.S.I, reflect the breeding cycle and spawning intensity.

The N.S.I of 238 female Loligo forbesi determined from (Fig. 2), the seasonal N.S.I variation run more or less parallel to those of the G.S.I seasonal variations (Fig. 2). It was found minimal in autumn and gradually increases attaining its highest values in summer. This confirms the previous conclusion from G.S.I study that spawning occurs during spring and early summer. 


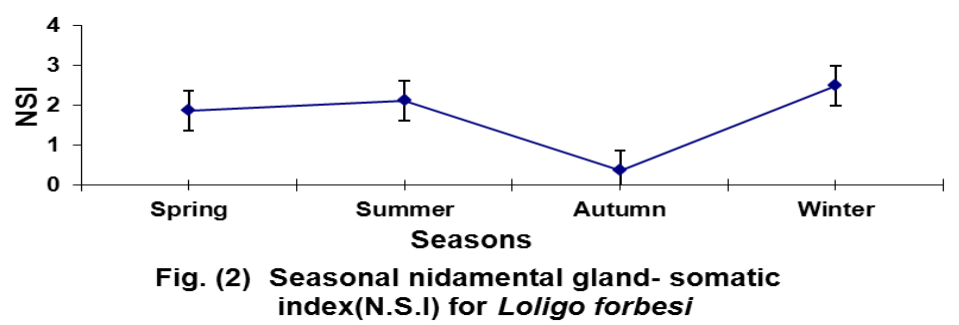

\section{2- Maturity stages}

In order to define different maturity stages in males we have to detect the presence of spermatophores in the Needham's sac. On the other hand, egg size and color of accessory nidamental gland are good tools for the females. Present results obtained classified maturity as two stages for males (immature and mature), five stages for females (immature, maturing, mature, ripe and spent). Stage I- immature, testes can be easily recognized externally, there are no spermatophores in Needham's sac. In females the eggs are small and accessory nidamental gland is white in color. Stage II - maturing, in females the eggs are medium sized and the accessory nidamental gland is orange in color. Stage III - mature Needham's sac can be easily recognized filled with spermatophores. For females the eggs are large sized and the accessory nidamental gland is red in color. Stages IV - ripe, in females the eggs are large and the color of the accessory nidamental gland is coral. Stage V - spent, in females no ripe eggs remain and the accessory nidamental gland is rose in color.

\section{Seasonal variation}

Seasonal variations of maturity stages during the period between spring 2010 and winter 2011 for male and female Loligo forbesi are graphically represented in (Figs. 3 \& 4) respectively. It is clear that mature males appeared throughout the year, while ripe females appeared in summer and winter. Immature males and females first appeared in the catch during summer and became dominant in autumn. Therefore, Loligo forbesi spawning season (as indicated by the significant higher frequency of mature males and ripe females) occurs during spring and early summer.

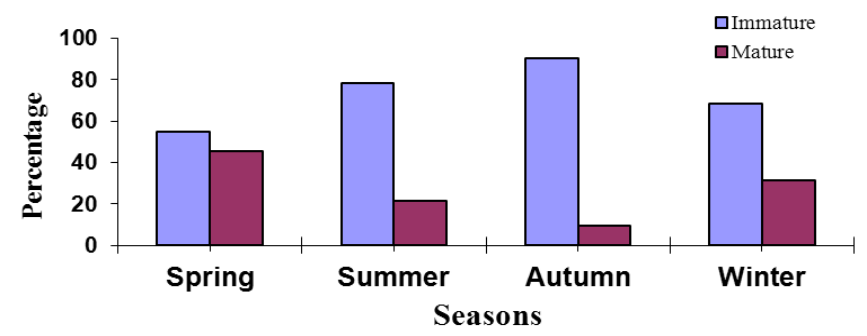

Fig. (3) Seasonal distribution of maturity stages for male Loligo forbesi

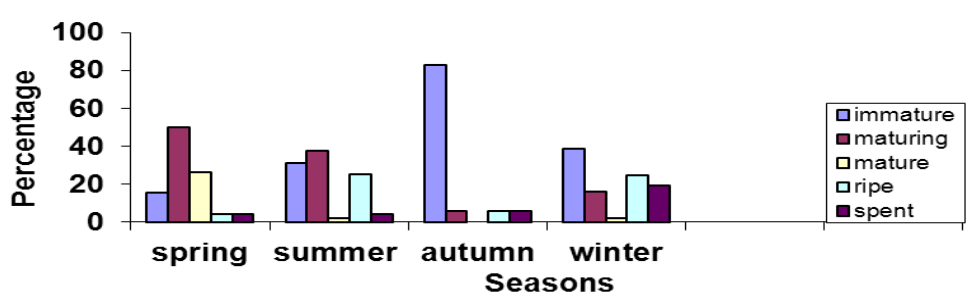

Fig. (4) Seasonal distribution of maturity stages for female Loligo forbesi 


\section{3- Size at first maturity}

Knowledge about size at first sexual maturity has its practical application in determining the minimum legal size that may be needed to secure a spawning part of a fish population. In the present work, Loligo forbesi maturity was studied throughout the year. The percentages of mature Loligo forbesi at $1 \mathrm{~cm}$. length intervals for both sexes and relationship with mantle length are graphically illustrated in Fig. 5. Present results obtained clarify that all individuals less than $9 \mathrm{~cm}$. and $10 \mathrm{~cm}$. mantle lengths are immature for Loligo forbesi males and females, respectively. The majority of Loligo forbesi individuals longer than $12 \mathrm{~cm}$. and $11 \mathrm{~cm}$. mantle length are mature for males and females, respectively. Snedcor (1956) stated that the length, at which $50 \%$ of the examined animals acquire a certain character, could be taken as the length representing the onset of that character. Accordingly it can be concluded that females Loligo forbesi attain their first sexual maturity at $11.8 \mathrm{~cm}$. mantle length, while the male at $13 \mathrm{~cm}$. mantle length (Fig. 5).

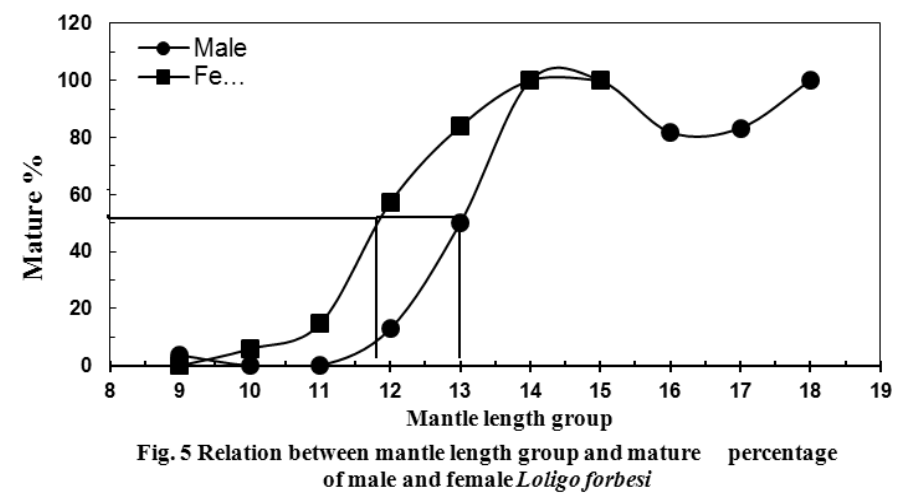

\section{4- Sex ratio}

of male and female Loligo forbesi

Table (1) illustrates the ratio of Loligo forbesi males to females in specimens examined. It appears that throughout all seasons, males outnumber females. Table (2) exhibits the ratio of immature to mature Loligo forbesi individuals for both sexes according to seasons. It is evident that, for males, immature outnumber matures throughout all seasons with high percentage in autumn. Mature females show a higher representation than immature ones throughout spring and summer, while immature females show higher existence than mature ones throughout autumn and winter. This confirms that spawning season occurs during spring and early summer.

Table 1: Seasonal ratio of male to female individuals for Loligo forbesi.

\begin{tabular}{|c|c|c|c|c|c|}
\hline Season & Total Number & Sex & Number & $\%$ & Ratios \\
\hline \multirow{2}{*}{ Spring } & \multirow{2}{*}{99} & Male & 53 & 53.54 & \\
\hline & & Female & 46 & 46.46 & $1.2: 1$ \\
\hline \multirow{2}{*}{ Summer } & \multirow{2}{*}{108} & Male & 60 & 55.56 & \\
\hline & & Female & 48 & 44.44 & $1.3: 1$ \\
\hline \multirow{2}{*}{ Fall } & \multirow{2}{*}{224} & Male & 137 & 61.16 & \\
\hline & & Female & 87 & 38.84 & $1.6: 1$ \\
\hline \multirow{2}{*}{ Winter } & \multirow{2}{*}{117} & Male & 60 & 51.28 & \\
\hline & & Female & 57 & 48.72 & $1.1: 1$ \\
\hline \multirow[b]{2}{*}{ All year } & \multirow[b]{2}{*}{548} & Male & 310 & 56.57 & \\
\hline & & Female & 238 & 43.43 & $1.3: 1$ \\
\hline
\end{tabular}


Table 2: Seasonal ratio of immature to mature male and female of Loligo forbesi.

\begin{tabular}{|c|c|c|c|c|c|c|c|c|}
\hline Season & $\begin{array}{c}\text { Male Total } \\
\text { Number }\end{array}$ & Maturity & Number & Ratios & $\begin{array}{c}\text { Female } \\
\text { Total } \\
\text { Number }\end{array}$ & Maturity & Number & Ratios \\
\hline Spring & 53 & $\begin{array}{l}\text { Immature } \\
\text { Mature }\end{array}$ & $\begin{array}{l}29 \\
24 \\
\end{array}$ & $1.2: 1$ & 46 & $\begin{array}{c}\text { Immature } \\
\text { Mature }\end{array}$ & $\begin{array}{c}9 \\
37 \\
\end{array}$ & $1: 4.1$ \\
\hline Summer & 60 & $\begin{array}{l}\text { Immature } \\
\text { Mature }\end{array}$ & $\begin{array}{l}47 \\
13 \\
\end{array}$ & $3.6: 1$ & 48 & $\begin{array}{c}\text { Immature } \\
\text { Mature }\end{array}$ & $\begin{array}{l}17 \\
31 \\
\end{array}$ & $1: 1.8$ \\
\hline Autumn & 137 & $\begin{array}{c}\text { Immature } \\
\text { Mature }\end{array}$ & $\begin{array}{c}124 \\
13 \\
\end{array}$ & $9.5: 1$ & 87 & $\begin{array}{c}\text { Immature } \\
\text { Mature }\end{array}$ & $\begin{array}{l}77 \\
10 \\
\end{array}$ & $7.7: 1$ \\
\hline Winter & 60 & $\begin{array}{l}\text { Immature } \\
\text { Mature }\end{array}$ & $\begin{array}{l}41 \\
19 \\
\end{array}$ & $2.2: 1$ & 57 & $\begin{array}{c}\text { Immature } \\
\text { Mature }\end{array}$ & $\begin{array}{l}33 \\
24 \\
\end{array}$ & $1.4: 1$ \\
\hline All year & 310 & $\begin{array}{c}\text { Immature } \\
\text { Mature }\end{array}$ & $\begin{array}{c}241 \\
69 \\
\end{array}$ & $3.5: 1$ & 238 & $\begin{array}{c}\text { Immature } \\
\text { Mature }\end{array}$ & $\begin{array}{l}136 \\
102 \\
\end{array}$ & $1.3: 1$ \\
\hline
\end{tabular}

\section{DISCUSSION}

Spawning seasons has been described for many loliginid squids; Loligo forbesi and Loligo vulgaris (Moreno et al., 1994), Loligo pealei (Lange and Sissenwine, 1980), Loligo opalescens (Hixon, 1983), Loligo gahi (Hatfield and Des Clers, 1998; Hatfield, 2000) and in chokka squid (Augustyn et al., 1994). It is worth to note that for most species, a single peak spawning episode occurs each year although two spawning peaks are suggested for Loligo gahi in Falkland Island waters (Hatfield, 2000) and for Loligo pealei in the NW Atlantic (Brodziak, 1998).

In the present study, the cycles of G.S.I, N.S.I, seasonal variation in the maturity stages and sex ratio show that spawning season for males and females Loligo forbesi occurs during spring and early summer. This spawning cycle is analogous to the cycle observed by other authors working in different regions of the world. Gabr \& Riad (2008) results for Suez Bay, Red Sea, Egypt Loligo forbesi and Kilada \& Riad (2008) for Mediterranean Sea and the Gulf of Suez, for the same species are in good accordance with present work results, which referred that the Suez Bay and Mediterranean Loligo forbesi spawn during spring and early summer. Pierce et al. (1994a) and Collins et al. (1995) observed that spawning of the same species in the British waters extended over a long period, peaking during winter and spring. In the Irish and Celtic seas spawning of Loligo forbesi occurs primarily during winter, with a peak in December. In the Scottish waters peak spawning of Loligo forbesi is slightly later (Lum-Kong et al., 1992; Boyle and Ngoile, 1993 and Pierce et al., 1994a). In the Faroe Bank Loligo forbesi was reported to spawn mainly in April and May, but with some spawning at other times of year (Gaard, 1987). The Rockall Bank squid were suggested by Pierce et al. (1994a) to be an additional offshore population of Loligo forbesi which recruits in spring, appearing in summer on the Rockall Bank and probably spawning occurs during summer. Pierce et al., (1994a) recorded mature animals on the Rockall Bank in autumn, but he is not sure if spawning occurs there or not. Guerra \& Rocha (1994) observed that, breeding season of Loligo forbesi from Galician waters (NW Spain) extends during winter and spring, with intensive spawning during winter.

It is worth mentioning that Loligo forbesi seasonal spawning peaks in winter or spring were reported in the British waters (Holme, 1974; Howard et al., 1987; Boyle and Ngoile, 1993) and off the Faroes (Gaard, 1987); nevertheless spawning occurs at other times during the year. Holme (1974) suggested a summer spawning for Loligo forbesi in the English Channel. In the Azores islands, the highest values of the gonado- somatic index (G.S.I) were recorded during winter and spring (Porteiro and Martins, 1994). Lum-Kong et al. (1992) recorded spawning females in the Scottish waters during winter and spring, with a peak of spawning occurring in spring; eggs have also been found in summer, which suggests that there is an extended spawning season in the Scottish waters. Moreno et al. (1994) indicated that off the Portuguese coast, spawning takes place in autumn and winter. Pierce et al. 
(1994a) stated that, breeding season for Loligo forbesi in the Scottish waters extends during winter and spring like the same as recorded by Ngoile (1987), Lum- Kong et al. (1992) and Boyle and Ngoile (1993) in previous studies on the Scottish population. Pierce et al. (1994a) advocated that, recruitment of both sexes apparently occurred primarily in spring, summer and early autumn; with some small and immature animals existing all the year round. On the other hand, Pierce et al. (2005) stated that, breeding season for Loligo forbesi in the Scottish waters extends during winter and summer. In the Azores, Martins (1982) found mature Loligo forbesi represented in samples from the fishery catch throughout the year, but with a highest degree of maturity in spring. It is likely that spawning areas exist in the north-western part of the North Sea (Oesterwind et al., 2010). Loligo forbesi spawning is considered intermittent and terminal, meaning several batches of eggs are laid and death occurs at the end of the spawning season after all of the eggs are laid (Rocha and Guerra, 1996; Macewicz et al. 2004). Changes in the accessory organs can be used to identify trends in maturation and growth of Loligo forbesi in the Scottish waters (Smith et al., 2005). The exploited population of Loligo forbesi in the Galician waters was found to be composed of two groups; one formed by individuals hatched in winter- spring and another by specimens hatched in summerautumn. The same two groups were also observed in Loligo vulgaris (Rocha and Guerra, 1999).

This indicates that the spawning season and the reproductive peak of Loligo forbesi are remarkably flexible and probably this may be attributed to environmental conditions prevailing as Mangold- Wirz (1963) considered temperature and light as the most important external factors that influence sexual maturation in cephalopods.

For maturity stages, in the present study four female sexual maturity stages and two for males have been defined. Loligo forbesi sexual maturity scales have already been described by several authors. Results of the maturity process and spawning season of Loligo forbesi obtained in the present study are similar to those found by Howaida \& Riad (2008) who stated that three maturity stages for Loligo forbesi in the Suez Bay, Red Sea, Egypt were encountered in both sexes and they added that seasonal variation in the maturity stages and maturity indices show that the mature animals of both Loligo forbesi sexes can be found throughout most of the year with spawning peak for both sexes occurring during spring and early summer. Three maturity indices for males and females Loligo forbesi in the Azores were applied. Both sexes showed highest maturity values in winter and spring, lowest in autumn, but mature squids were found in all monthly samples (Porteiro \& Martins, 1994). For all maturity classes, higher abundance in winter and spring was associated with deeper water, while higher abundance in summer and autumn was associated with shallower water, consistent with seasonal onshore- offshore migrations but suggesting that most spawning may take place in deeper waters. In the Scottish waters for example, there is a seasonal effect on maturity with individuals having a higher probability of being mature in winter and spring than in summer and autumn (Pierce et al., 2005). Loligo forbesi mature adults in the Scottish waters were found in commercial samples throughout early and late parts of the year. Immature squid exists in the commercial samples, although with varying abundance, in all months for which there are data except March when the entire sample was mature. The proportion of maturing and mature males in the samples increased from July (summer) onwards, with the highest proportion of mature males in March (spring) (Lum- Kong et al., 1992). The earlier appearance of mature males Loligo forbesi in the Scottish waters in winter samples suggests that males mature earlier than females (Howard et al., 1987; Ngoile, 1987) and also for other loliginids, including Sepioteuthis arctipinnis (Rao, 1954) and Alloteuthis subulata (Rodhouse et al., 1988). In the Azores, mature Loligo forbesi are present in catches all the year round (Martins, 1982; Martins \& Porteiro, 1988). Forsythe \& Hanlon (1989) suggested that, small immature squids are apparently represented in the population in most 
months, suggesting that recruitment occurs throughout the year, as might be expected, giving an extended spawning season showing the effects of seasonal differences in water temperature and food abundance on growth rates of hatchlings. Some cephalopod species clearly exhibit decreasing somatic growth rates with increasing sexual maturation (Arkhipkin and Silvanovich 1997; Arkhipkin et al., 1998). According to Guerra and Rocha (1994), maturation was apparent from November to April, as indicated by the increasing proportion of maturing (stage III) and mature (stages IV and V) squids. Mature Loligo forbesi males exist from February to July and male maturity increased from September to April. Boyle et al. (1995) stated that, maturity can be categorized on a scale as I (immature) to V (mature) for males and females Loligo forbesi in the Scottish waters. In the Irish waters, the main recruitment of Loligo forbesi occurs in the summer (Collins et al., 1995), at a similar time and size to that described by Holme (1974) for the English Channel. The second period of recruitment in December may be equivalent to the weak November recruitment reported by Boyle and Ngoile (1993) in the Scottish waters. It is worth to note that, Boyle and Ngoile (1993) and Pierce et al. (1994a) referred to April recruitment in the Scottish waters, which probably is contributed to the Rockall Bank fishery, but there was no evidence of recruitment at this time in the Irish or Celtic Seas. Three maturity indices for females and males Loligo forbesi in the Azores were applied. High percentages of mature squid (stages IV - V) represent $87.4 \%$ of the females and $81 \%$ of the males. Stage IV males were the least frequently encountered. Spent females were not found but spent males were grouped with stage V squid as they still had functional spermatophores (Porteiro and Martins, 1994). Mature and immature- maturing squid exist simultaneously on the same grounds and males reach maturity before females, as pointed by Collins et al. (1993). It is known that fertilization is close to $100 \%$ (Segawa et al., 1988; Hanlon et al., 1989) but very little is known about the mating strategy of this species. The presence of mature spermatophores in the penis, while the Needham's sac contains very few, can be an argument for this assumption. Low numbers of stage IV males have also been observed for other areas e.g. Portuguese (Moreno et al., 1994) and the use of stages IV and V combined was adopted by Guerra and Rocha (1994).

For length at first maturity, present work results revealed that, males Loligo forbesi grew to a large size than females; the maximum size for males was $25 \mathrm{~cm}$. mantle length while for females was $17 \mathrm{~cm}$. mantle length. Male loliginids typically exhibit greater range of size than females (Worms, 1983; Rodhouse et al., 1988; Hatfield et al., 1992). In the present study, the size at first sexual maturity for males and females Loligo forbesi, was estimated to be at $13 \mathrm{~cm}$. and $11.8 \mathrm{~cm}$, respectively. Howaida \& Riad (2008) estimated first maturation at $10.6 \mathrm{~cm}$. and $10.4 \mathrm{~cm}$. mantle lengths for males and females Loligo forbes, respectively for individuals dwelling the Suez Bay, Red Sea, Egypt. Collins et al. (1995) recorded first maturation at $12 \mathrm{~cm}$. and $15 \mathrm{~cm}$. mantle length for male and female Loligo forbesi, respectively in catches off the east coast of Ireland. The smallest mature male and female Loligo forbesi in Galician waters was $12.2 \mathrm{~cm}$. and $16 \mathrm{~cm}$. mantle length, respectively (Guerra \& Rocha, 1994); their higher value may be a result of selectively sampling larger animals of commercial catches. According to Thomas et al. (1999), length at first maturity for Loligo forbesi did not show significant between northern fisheries (Scotland and the English Channel) and southern fisheries (Portugal and Azores) which are significantly higher in the south than in the north. Pierce et al. (2005) recorded that, the size at first sexual maturity for males and females Loligo forbesi from the Scottish waters was $10 \mathrm{~cm}$. and 11 $\mathrm{cm}$. mantle length, respectively. Maturity of the Veined Squid occurs at a range of sizes, with males typically growing to a larger size than females (Hastie et al. 2009); but maturity is typically reached by $20 \mathrm{~cm}$. mantle length (Challier et al. 2005). In common with many loliginid squids, there are at least two different sizes at maturity classes in male Loligo forbesi 
throughout its range (Guerra and Rocha, 1994; Moreno et al., 1994; Porteiro and Martins, 1994; Collins et al., 1995; Boyle et al., 1995). Lum- Kong et al. (1992) stated that, the minimum size at maturity was $14 \mathrm{~cm}$. for males Loligo forbesi in the Scottish waters, while the minimum size at maturity for females was $15 \mathrm{~cm}$.

For sex ratio, in the present work, males of Loligo forbesi in the samples constituted almost $56.57 \%$ of the specimens collected and predominate through all seasons. This value varies in different authors findings. Loligo forbesi males in the Azores waters constitute $59 \%$ (Martins, 1982). Thomas et al. (1999) stated that, males Loligo forbesi in the Northeast Atlantic are more dominant. Scotland samples suggest predominance of females during periods of breeding activity (Pierce et al., 1994b). Females Loligo forbesi in the Azores waters were dominating in winter, without showing a significant variation from the ratio 1:1; however in spring, males increased in number and in autumn, they were significantly more abundant than females (Porteiro and Martins, 1994). Males Loligo forbesi in Galician waters were significantly more abundant than females during spring and summer, females only outnumbered males in November ( Guerra and Rocha, 1994). Pierce et al. (1994a) stated that, females Loligo forbesi in the Scottish waters exhibit predominance in the majority of samples and were consistently more numerous during autumn, winter and early spring, with the proportion of females being highest at the peak of the breeding season (late winter and early spring). Conversely, males tended to be more abundant in samples containing the most small and immature animals during spring and summer. Thus, it could be concluded that males both recruit to the fished population and disappear from the fished population earlier than females. Poteiro and Martins (1994) concluded that, the predominance of immaturematuring Loligo forbesi in the Azores during autumn might suggest the existence of an optimum spawning peak.

It is worth to note that in the Egypt waters (Suez Bay, Red Sea) males outnumbered females in all seasons except summer (Howaida and Riad, 2008). They explained that the difference between male and female abundance could be due to catch bias rather than to population structure, where the small sample sizes need to be taken into consideration. Pierce et al. (1994a) investigated Loligo forbesi in the Scottish waters, and Guerra and Rocha (1994) studied Loligo vulgaris in the Spanish waters, found that the sex ratio is related to the type of gear, while equal sex ratios were apparent throughout the year except in the peakspawning period, when females were more numerous than males. Augustyn (1990) and Augustyn et al. (1994) have previously reported a biased ratio in favor of males for chokka on the spawning grounds. This has been reported for other Loligo species i.e. Loligo vulgaris from the Algarve region in southern Portugal (Coelho et al., 1994) but these estimates were based on jig caught samples and skewed ratios could reflect more attacks on the jigs by males than females rather than greater male abundance (Lipinski, 1994). In the present study, Loligo forbesi were only encountered as a bycatch of trawling techniques.

\section{REFERENCES}

Arkhipkin, A.I.; Laptikhovsky, V.V.; Nigmatullin, C.M.; Bespyatykh, A.V. and Murzov, S.A. (1998). Growth, reproduction and feeding of the tropical squid Ornithoteuthis antillarum (Cephalopoda, Ommastrephidae) from the central-east Atlantic. Sci. Mar., 62: 273-288.

Arkhipkin, A.I.and Silvanovich, N.V. (1997). Age growth and maturation of the squid Martialia hyadesi (Cephalopoda, Ommastrephidae) in the south-west Atlantic. Antarct. Sci., 9: 373-380. 
Augustyn, C. J. (1990). Biological studies on the chokker squid Loligo vulgaris reynaudii (Cephalopoda: Myopsida) on spawning grounds off the southeast coast of South Africa. S. Afr. J. Mar. Sci., 9: 11-26.

Augustyn, C. J.; Lipinski, M. R; Sauer, W. H. FL; Roberts, M. J. and Mitchell-innes, B. A. (1994). Chokka squid on the Agulhas Bank: life history and ecology. S. Afr. J. Sci., 90: 143-153.

Bakhayokho, M. (1983). Biology of the cuttlefish Sepia officinalis hierredda off the Sengalese coast In: J. P. Caddy (Editor). Advances in Assessment of World CephaJopod Resource. FAO fish. Tech. Pap., 231: 204-263.

Boyle, P.R. and Ngoile, M.A.K. (1993). Assessment of maturity state and seasonality of reproduction in Loligo forbesi (Cephalopoda: Loliginidae) from Scottish waters. In Recent advances in Sherries biology (ed. T. Okutani et al.), pp. 37- 48. Tokyo: Tokai University Press.

Boyle, P.R.; Pierce, G.J.and Hastie, L.C. (1995). Flexible reproductive strategies in the squid Loligo forbesi. Mar. Biol., 121: 501-508.

Brodziak, J. K. T. (1998). Revised biology and management of long-finned squid (Loligo pealei) in the northwest Atlantic. Cal COFI Rep., 39: 61-69.

Challier, L.; Pierce, G.J. and Robin, J. (2005). Spatial and temporal variation in age and growth in juvenile Loligo forbesi and relationships with recruitment in the English Channel and Scottish waters. J. Sea Res., 55:217-229.

Coelho, M. L.; Quintela, J.; Bettencourt,V.; Olavo, G. and Villa, H. (1994). Population structure, maturation patterns, and fecundity of the squid Loligo vulgaris from southern Portugal. Fish. Res., 21: 87-102.

Collins, M.A.; Burnell, G.M. and Rodhouse, P.G. (1993). Recruitment, maturation and spawning of the Loligo forbesi Steenstrup in the Irish and Celtic seas. International Council for Exploration of the Sea (ICES), C.M. 1993/ K: 43-11 pp.

Collins, M.A.; Burnell, G.M. and Rodhouse, P.G. (1995). Recruitment, maturation and spawning of Loligo forbesi (Steenstrup Cephalopoda: Loliginidae) in Irish waters. ICES J. Mar. Sci., 52:127-137.

Collins, M. A.; Boyle, P. R.; Pierce, G. J.; Key, L. N.; Hughes, S. E., and Murphy, J. (1999). Resolution of multiple cohorts in the Loligo forbesi population from the west of Scotland. ICES J. Mar. Sci., 56: 500-509.

Collins, M. A.; Pierce, G. J. and Boyle, P. R. (1997). Population indices of reproduction and recruitment in Loligo forbesi (Cephalopoda: Loliginidae) in Scottish and Irish waters. J. Appl. Ecol., 34: 778-786.

Cunha, M. M. and Moreno, A. (1994). Recent trends in the Portuguese squid fishery. Fish. Res., 21: 231-241.

Forsythe, J. W. and Hanlon, R.T. (1989). Growth of the eastern Atlantic squid, Loligo forbesi Steenstrup (Mollusca: Cephalopoda). Aauacult. Fish. Manag., 20: 1-14.

Gaard, E. (1987). An investigation of the squid Loligo forbesi Steenstrup on Faroe Bank. International Council for the Exploration of the Sea (CM Papers and Reports), CM 1987/K: 18.

Gabr, H.R. and Riad, R. (2008). Reproductive biology and morphometric characters of the squid Loligo forbesi (Cephalopoda: Loliginidae) in the Suez Bay, Red Sea, Egypt. Egypt J. Aquat. Biol. Fish., 12: 59- 73.

Guerra, A. and Rocha, F. (1994). The life history of Loligo vulgaris and Loligo forbesi (Cephalopoda: Loliginidae) in Galician waters (NW Spain). Fish. Res., 21:43-69.

Hanlon, R.T.; Yang, W.T.; Turk, P.E.; Lee, P.G. and Hixon, R.F. (1989). Laboratory culture and estimated life span of the eastern Atlantic squid, Loligo forbesi Steenstrup, 1856 (Mollusca: Cephalopoda). Aquacult. Fish. Manag., 20: 15-34. 
Hastie, L.; Pierce, G.; Pita, C.; Viana, M.; Smith, J. and Wangvoralak, S. (2009). Squid fishing in UK waters. University of Aberdeen. $84 \mathrm{pp}$.

Hatfield, E. M. C. (2000). Do some like it hot? Temperature as a possible determinant of variability in the growth of Patagonian squid Loligo gahi (Cephalopoda: Loliginidae). Fish. Res., 47: 27- 40.

Hatfield, E. M. G. and Des Clers, S. (1998). Fisheries management and research for Loligo gahi in the Falkland Islands. CalCOFI Rep., 39: 81-99.

Hatfield, E.M.C.; Rodhouse, P.G.and Barber, D.L. (1992). Production of soma and gonad in maturing female Illex 85rgentines (Mollusca: Cephalopoda). J. Mar. Biol. Assoc. UK, 72: 281-291.

Hixon, R. F. (1983). Loligo opalescens, R 95-114. In: P. R. Boyle (Editor), Cephalopod Life Cycles, Vol. I, Comparative reviews. Academic Press, London. 441 pp.

Holme, N.A. (1974). The biology of Loligo forbesi (Steenstrup: Mollusca, Cephalopoda) in the Plymouth area. Journal of the Marine Biological Association of the United Kingdom, 54:481-503.

Howard, F. G. (1979). Recent trends in the Scottish fishery for Loligo forbesi, together with some notes on the biology of the species. ICESCM 1979/K: 36.

Howard, F.G.; Ngoile, M.A., and Mason, J. (1987). Lolifgo forbesi its present status in Scottish fisheries. ICES CM 1987/k: 5.

Joy, M. (1989). The fishery biology of ommastrephid squid in Shetland water. MSc. Thesis, University of Aberdeen, 118pp.

Kilada, R. and Riad, R. (2008). Seasonal variations in biochemical composition of Loligo forbesi (Cephalopoda: Loliginidae) in the Mediterranean Sea and the Gulf of Suez, Egypt. J. Shellfish Res., 27(4): 1-7.

Lange, A. M. T. and Sissenwine, M. P. (1980). Biological considerations relevant to the management of squid (Loligo pealei and Hlex illecebrosus) of the northwest Atlantic. Mar. Fish. Rev., 42: 23-38.

Lipinski, M. (1979). Universal maturity scale for the commercially important squids. The results of maturity classification of the Illex illecebrosus (Lesueur, 1821) population for years 1973-1977. Res. Doc. 79/11/38. Serial No. 5364, International Commission for Northwest Atlantic Fisheries, 40 pp.

Lipinski, M. (1994). Differences among basic biological parameters in a population of chokka squid Loligo vulgaris reynaudii (Cephalopoda: Loliginidae) sampled by three methods. S. Afr. J. mar. Sci., 14: 281-286.

Lum-Kong, A.; Pierce, G. J. and Yau, C. (1992).Timing of spawning and recruitment in Loligo forbesi Steenstrup (Cephalopoda: Loliginidae) in Scottish Waters. J. Mar. Biol. Assoc.UK, 72: 301-311.

Macewicz, B.J; Hunter, J.R; Lo, N.C.H; LaCasella, E.L. (2004). Fecundity, egg deposition, and mortality of market squid (Loligo opalescens). Fish Bull, 102:306-327.

Mangold-Wirz, K. (1963). Biologie des Cephalopodes benthiques et nectoniques de la Mer Catalane. Vie et Millieu, 13:285.

Martins, H.R. (1982). Biological studies of the exploited stock of Loligo forbesi (Cephalopoda) in the Azores. Journal of the Marine Biological Association of the UK, 62:799-808.

Martins, H.R. and Porteiro, F.M. (1988). The exploited stock of Loligo forbesi in the Azores: additional notes on biology and fisheries. International Council for the Exploration of the Sea (CM Papers and Reports), CM 1988/K: 8, 7 pp.

Moreno, A.; Cunha, M.M. and Pereira, J.M.F. (1994). Population biology of the veined squid (Loligo forbesi) and European squid (Loligo vulgaris) from the Portuguese coast. Fish. Res., 21:71-86. 
Ngoile, M.A.K. (1987). Fishery biology of the squid Loligo forbesi (Cephalopoda: Loliginidae) in Scottish waters. Ph.D. Thesis, University of Aberdeen.

Oesterwind, D.; Hofstede, R.; Harley, B.;Brendelberger, H. and Piatkowski, U. (2010). Biology and meso-scale distribution patterns of North Sea cephalopods. Fish. Res., 106:141-150.

Pierce, G. J.; Boyle, P. R. L; Hastie, L.C. and Begora Santos, M. (1994a). Diets of squid Loligo forbesi and Loligo vulgaris in the northeast Atlantic. Fish. Res., 21: 149- 163.

Pierce, G.J.; Boyle, P.R.;Hastie, L.C. and Key, L. ( 1994b). The life history of Loligo forbesi in Scottish waters. Fish. Res., 21:193-216.

Pierce, G. J.; Zuur, A. F.; Smith, J. M.; Santos, M. B.; Bailey, N.; Chen, C. S.; Boyle, P. R. (2005). Interannual variation in life-cycle characteristics of the veined squid (Loligo forbesi) in Scottish (UK) waters. Aquat. Living Res., 18: 327-340.

Pierce, G. J.; Bailey, N.; Stratoudakis, Y. and Newton, A. (1998). Distribution and abundance of the fished population of Loligo forbesi in Scottish waters: analysis of research cruise data. ICES. J. Mar. Sci., 55: 14-33.

Porteiro, F.M. and Martins, H. (1994). Biology of Loligo forbesi Steenstrup, 1856 (Mollusca: Cephalopoda) in the Azores: simple composition and maturation of squid caught by higging. Fish. Res., 21:103-114.

Rao, K.V. (1954). Biology and fishery of the Palk-Bay Squid, Sepioteuthis arctipinnis Gould. Indian Journal of Fisheries, 1: 37-66.

Riad, R. (1993). Studies on cephalopod molluscs of the Mediterranean waters of Alexandria. M.Sc. Thesis, Deapartment of Oceanography, Faculty of Science, Alexandria Univ., $167 \mathrm{pp}$.

Riad, R. and Abd El-Hafez, S. M. (2008). Bio-economic study of squid from Egyptian Red Sea. Egypt. J. Aquat. Res., 34.

Richard, A. (1967). Influence de la temperature et dela nutrition sur la forme et sla striation de lacoquille de Sepia officinalis. Comptes Rendus de la Sociitt Biologique, 161: 620624.

Rizkalla, S. I. (1992). Studies on the fishery biology of sea breams(Genus: Pagellus) in the Egyptian Mediterranean waters. Ph.D. Thesis, Facul., Sci., Zagazig Univ. 235 pp.

Rocha, F. and Guerra, A. (1996). Signs of an extended and intermittent terminal spawning in the squids Loligo vulgaris Lamarck and Loligo forbesi.

Rocha, F. and Guerra, A. (1999). Age and growth of two sympatric squid Loligo vulgaris and Loligo forbesi, in Galician waters (north-west Spain). J. Mar. Biol. Assoc. UK, 79: 697-707.

Rodhouse, P. G.; Swinfen, R. C. and Munay, A. W. A. (1988). Life cycle, demography and reproductive investment in the myopsid squid Alloteutbis subulata. Mar. Ecol. Prog. Ser., 45: 245-253.

Roper, C. F. R.; Sweeney, M. J. and Nauen, C. E. (1984). FAO species catalogue- Vol.3.

Cephalopods of the world. An annotated and illustrated catalogue of species of interest to fisheries. Fish. Synopsis 125, vol.3, FAO, Rome, 277 pp.

Segawa, S.; Yang, W.T.; Marthy, H.-J. and Hanlon, R.T.( 1988). Illustrated embryonic stages of the eastern Atlantic squid Loligo forbesi. The Veliger, 30: 230-243.

Snedecor, G.W. (1956). Statistical methods applied to experiments in Agriculture and biology. Iowa state Univ., Press, U.S.A. 534 pp.

Smith, J.F.; Pierce, G.J; Zuur, A.F; Boyle, P.R. (2005). Seasonal patterns of investment in reproductive and somatic tissues in the squid Loligo forbesi. Aquat Living Resour, 18:341-351.

Thomas, M.; Challier, L.; santos, M.B.; Pierce, G.J.; Moreno, A.;Pereira, J.;Cunha, M.M.; Porteiro, F.; Goncalves, J. and Robin, J.P. ( 1999). Spatial differences in biological 
characteristics of Loligo forbesi (Cephalopoda: Loliginidae) in the Northeast Atlantic. International Council for the Exploration of the Sea, 1-7.

Worms, J. (1983). Loligo vulgaris. In Cephalopod Life Cycles. Vol. 1.Species Accounts (ed. P.R. Boyle), pp. 143, 157. London: Academic Press.

Young, K. M.; Bartlett, P. F. and Coulson, E. J. (2006). Neural progenitor number is regulated by nuclear factor-kappaB p65 and p50 subunit-dependent proliferation rather than cell survival. J Neur. Res., 83: 39-49.

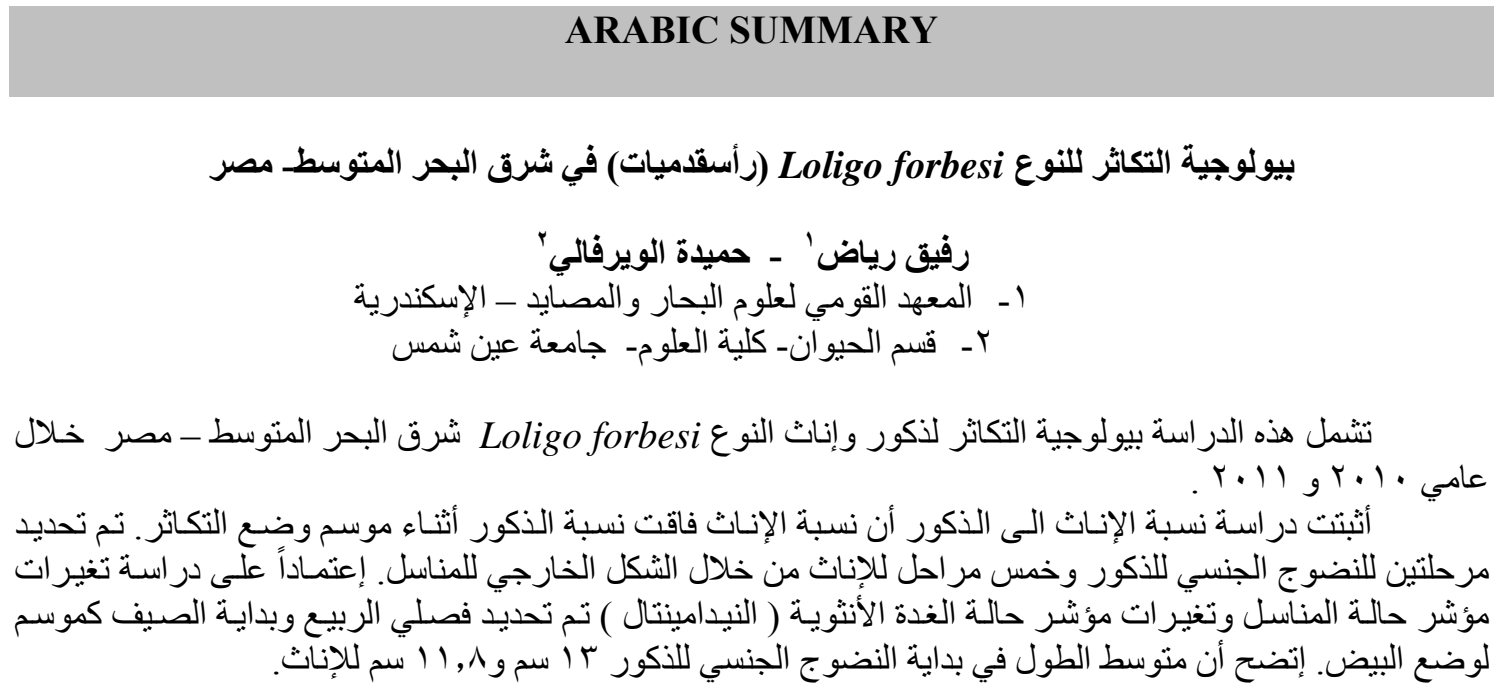

